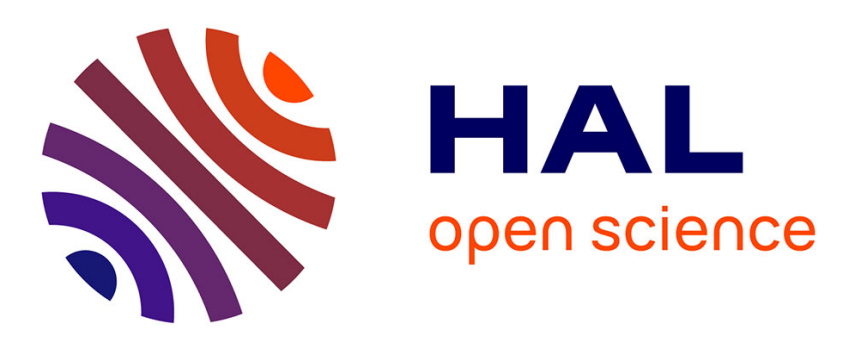

\title{
Esophageal diverticulum after peroral endoscopic myotomy Think about it if the symptoms change
}

R. Olivier, T. Wallenhorst, E. Coron, C. Brochard

\section{To cite this version:}

R. Olivier, T. Wallenhorst, E. Coron, C. Brochard. Esophageal diverticulum after peroral endoscopic myotomy Think about it if the symptoms change. Digestive and Liver Disease, 2019, 51 (6), pp.908. 10.1016/j.dld.2019.01.023 . hal-02089014

HAL Id: hal-02089014

https://hal-univ-rennes1.archives-ouvertes.fr/hal-02089014

Submitted on 15 Apr 2019

HAL is a multi-disciplinary open access archive for the deposit and dissemination of scientific research documents, whether they are published or not. The documents may come from teaching and research institutions in France or abroad, or from public or private research centers.
L'archive ouverte pluridisciplinaire HAL, est destinée au dépôt et à la diffusion de documents scientifiques de niveau recherche, publiés ou non, émanant des établissements d'enseignement et de recherche français ou étrangers, des laboratoires publics ou privés. 


\title{
ESOPHAGEAL DIVERTICULUM AFTER PERORAL ENDOSCOPIC MYOTOMY : THINK ABOUT IT IF THE SYMPTOMS CHANGE
}

\author{
Raphael Olivier ${ }^{1,2}$, Timothée Wallenhorst ${ }^{3}$, Emmanuel Coron ${ }^{1,2}$, Charlène Brochard ${ }^{1,3,4,5}$
}

1) Institut des Maladies de l'Appareil Digestif, IMAD, CHU Nantes, Hôpital Hôtel-Dieu, Place Alexis Ricordeau, 44093, Nantes, France

2) Université de Nantes, INSERM, IMAD, The enteric nervous system in gut and brain disorders, Université Bretagne Loire, Nantes, France

3) Service des Maladies de l'Appareil Digestif, CHU Rennes Pontchaillou, Rennes, France

4) Service d'Explorations Fonctionnelles Digestives, CHU Rennes Pontchaillou, Rennes, France

5) Université de Rennes 1, CIC1414, groupe INPHY, CHU Rennes Pontchaillou, Rennes, France

Peroral endoscopic myotomy (POEM) is one of the treatment of achalasia (1). A 58-year-old woman presented with daily dysphagia and weekly regurgitations. The results of high resolution esophageal manometry gave rise to a diagnosis of a type II achalasia. After 2 pneumatic balloon dilatations which were not effective, a POEM was performed. The patient presented daily regurgitations 6 months after the POEM. High resolution esophageal manometry was not contributive because the catheter did not pass through the esophagogastric junction. The gastroscopy was performed by an experienced endoscopist (TW) and demonstrated an esophageal food stasis and large esophageal pocket of $4 \mathrm{~cm}$. The esophagogastric junction (Fig 1) was eccentric and passed with jump. A conventional esophageal manometry with endoscopy-assisted placement was then performed and confirmed the impaired esophagogastric junction opening. A CT barium esophagram (Fig 2) demonstrated a focal saccular dilatation (diverticulum) of the esophagus approximately $4 \mathrm{~cm}$ long that was not seen on the CT barium done before the POEM. There was also moderate narrowing of the esophagogastric junction, leading to retention of a barium pill. These data explained the symptoms of the patient. Thus, if the symptoms of achalasia have changed, especially after POEM, gastroscopy, barium esophagram, and esophageal manometry are needed and the diverticulum must be evoked.

Disclosure: All authors disclosed no financial relationships relevant to this publication. 


\section{References}

(1) Schlottmann F, Luckett DJ, Fine J, Shaheen NJ, Patti MG. Laparoscopic Heller Myotomy Versus Peroral Endoscopic Myotomy (POEM) for Achalasia:

A Systematic Review and Meta-analysis. Ann Surg. 2018;267:451-460. 
Figure 1

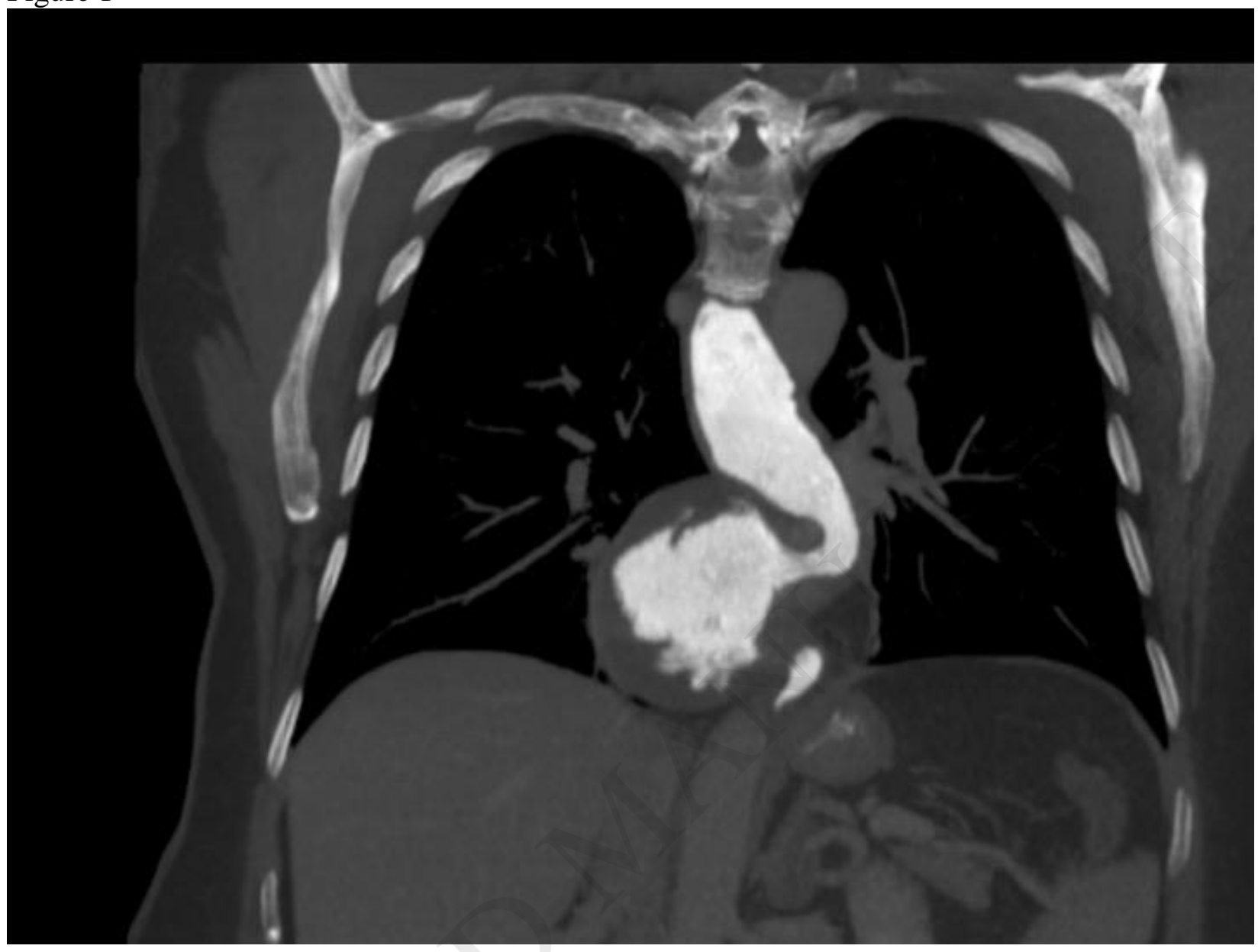

Figure 2 


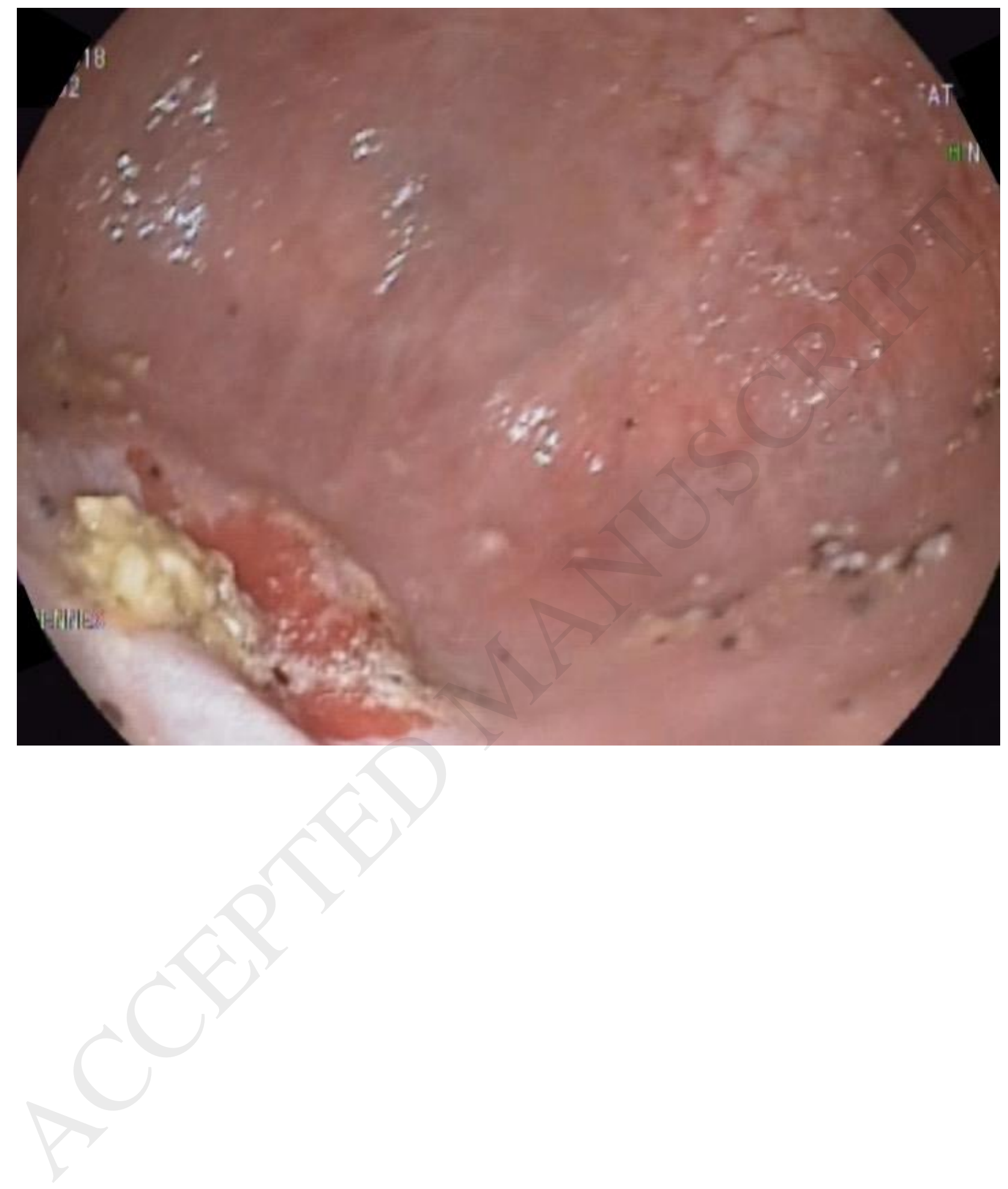

